\title{
Vertical gardens: Manufacturing materials proposal
}

\author{
Jardins verticais: Proposta de materiais para confecção \\ Jardines verticales: Propuesta de materiales de fabricación
}

Received: 06/01/2021 | Reviewed: 06/09/2021 | Accept: 06/14/2021 | Published: 06/27/2021

\author{
Liliane Sayuri Oyama \\ ORCID: https://orcid.org/0000-0001-7173-7796 \\ Universidade Estadual Paulista "Júlio de Mesquita Filho", Brazil \\ E-mail: lilioyama24@gmail.com \\ Maximiliano Kawahata Pagliarini \\ ORCID: https://orcid.org/0000-0001-7408-6327 \\ Universidade Federal da Grande Dourados, Brazil \\ E-mail:mpagliarini@ufgd.edu.br \\ Camila Miranda Buschieri \\ ORCID: https://orcid.org/0000-0002-5900-8993 \\ Universidade Estadual Paulista “Júlio de Mesquita Filho”, Brazil \\ E-mail: camilabuschieri@hotmail.com \\ Patrick Luan Ferreira dos Santos \\ ORCID: https://orcid.org/0000-0002-1956-1030 \\ Universidade Estadual Paulista “Júlio de Mesquita Filho", Brazil \\ E-mail: patricklfsantos@gmail.com \\ Regina Maria Monteiro de Castilho \\ ORCID: https://orcid.org/0000-0003-3421-7235 \\ Universidade Estadual Paulista "Júlio de Mesquita Filho”, Brazil \\ E-mail: regina.castilho@unesp.br
}

\begin{abstract}
Vertical gardens emerged with the aim of increasing green areas in large urban centres, thus reducing the negative impacts of this dense urbanization. In general, vertical gardens are able to improve air quality, reduce heat islands, increase biodiversity, among other advantages presented in this work. This study proposes the use of two materials for making panels for vertical gardens. The panels were based on the model developed by the French botanist Patrick Blanc, using "green felt" and "grey cacharel" with each panel measuring 50 x $80 \mathrm{~cm}$ and with 24 pockets. These were installed in a residence in the municipality of Ilha Solteira, São Paulo state, Brazil; having with vegetal species Trandescantia zebrina. During January 19 to February 2, 2020, the temperatures of the panels, the wall and the region behind the panels were measured. An average thermal damping of up to $8.71^{\circ} \mathrm{C}$ was observed; it was concluded that the panels developed were effective for the construction of vertical gardens.
\end{abstract}

Keywords: Vertical panels; Green walls; Green facades; Urban vegetation; Vertical vegetation.

\section{Resumo}

Os jardins verticais surgiram com o intuito de aumentar as áreas verdes nos grandes centros urbanos, diminuindo, assim, os impactos negativos dessa densa urbanização. Em geral, os jardins verticais são capazes de melhorar a qualidade do ar, diminuir as ilhas de calor, aumentar a biodiversidade, entre outras vantagens apresentadas neste trabalho. O presente estudo tem como proposta o uso de dois materiais para confecção de painéis para jardins verticais. Os painéis basearam-se no modelo desenvolvido pelo botânico francês Patrick Blanc, utilizando "feltro verde" e "cacharel cinza" tendo cada painel a dimensão de 50 x $80 \mathrm{~cm}$ e com 24 bolsilhos. Estes foram instalados em uma residência na cidade de Ilha Solteira - SP; tendo com espécie vegetal a Lambari - Trandescantia zebrina. Durante 19 de janeiro a 02 de fevereiro de 2020 foram aferidas as temperaturas dos painéis, do muro e da região atrás dos painéis. Observou-se um amortecimento térmico médio de até $8,71^{\circ} \mathrm{C}$; conclui-se que os painéis desenvolvidos foram efetivos para construção de jardins verticais.

Palavras-chave: Painéis verticais; Paredes verdes; Fachadas verdes; Vegetação urbana; Vegetação vertical.

\section{Resumen}

Los jardines verticales surgieron con el objetivo de incrementar las áreas verdes en los grandes centros urbanos, reduciendo así los impactos negativos de esta densa urbanización. En general, los jardines verticales son capaces de mejorar la calidad del aire, reducir las islas de calor, aumentar la biodiversidad, entre otras ventajas que se presentan en este trabajo. Este estudio propone el uso de dos materiales para la realización de paneles para jardines verticales. Los paneles se basaron en el modelo desarrollado por el botánico francés Patrick Blanc, utilizando "fieltro verde" y "cacharel gris" con cada panel de 50 x $80 \mathrm{~cm}$ y con 24 bolsillos. Estos fueron instalados en una residencia en la ciudad de Ilha Solteira - SP; teniendo con especies vegetales el Lambari - Trandescantia zebrina. Durante el 19 de enero al 2 
de febrero de 2020 se midieron las temperaturas de los paneles, la pared y la región detrás de los paneles. Se observó un amortiguamiento térmico promedio de hasta $8,71^{\circ} \mathrm{C}$; se concluye que los paneles desarrollados fueron efectivos para la construcción de jardines verticales.

Palabras clave: Paneles verticales; Paredes verdes; Fachadas verdes; Vegetación urbana; Vegetación vertical.

\section{Introduction}

Regarding urban population growth in recent years, there have been changes in city scenario. The increase in constructions and buildings led to decrease in green areas in urban centres, causing worsening air quality, increased average temperatures and noise, formation of heat islands, increased soil impermeability, changes in the ecosystem (Ekren, 2017).

Green areas are extremely important in people's lives inside cities, with psychological influence and visual impact being one of the main points. The vegetation present in the cities beneficially affects population health in several aspects: "The greener there is in a region, the lower the risk of mortality from non-accidental causes, especially cancer and respiratory diseases" (Saldiva, 2017).

Thus, vertical gardens are emerging as an alternative to reduce the negative impacts of urbanization in large cities. These are elements used in the internal or external walls of buildings, being covered by vegetation through specialized techniques.

The use of green gardens in buildings generates an improvement in temperature, air quality, reduction of heat islands, reduction of noise, influence of biodiversity, buildings aesthetics, reduction of energy costs and helps in rains water retention (Costa, 2011).

One of the exponents in the area was the French botanist Patrick Blanc, who started to install vertical gardens in the 1980s by himself and patented technology in several countries around the world (Blanc, 2008; Costa, 2011).

In Brazil, one of the main precursors of the idea of reconciling man with nature in the urban environment was Burle Marx, who, with his works performed between 1930 and 1980, transformed the concept of landscape and urban space in main brazilian cities (Lopéz \& Narváez, 2015), as an example the garden of Safra Bank, in São Paulo-SP/Brazil, when it used metal columns filled with coconut fibre, where epiphyte plants develop (Petty, 2008).

The method of vertical gardens construction with blankets is the most used today. This method, commonly used by Patrick Blanc, consists of three parts: a metal plate (usually aluminium), a PVC layer and a felt layer. The aluminium plate is hung on the wall, providing efficient thermal and acoustic insulation. The PVC layer is fixed to the aluminium plate, offering rigidity to the entire structure in addition to making it waterproof. Finally, the felt layer is installed over the PVC layer where the plants will be inserted. The high capillarity of the felt allows a homogeneous water distribution, facilitating the irrigation that is done by the top of the panel (Blanc, 2008).

Vertical gardens, in general, support a great diversity of plant species and, therefore, require more intense maintenance, especially in the replacement of nutrients from the substrate or water, behaving like hydroponic systems; this method of technology allows development in tall buildings or very large surfaces. (Sharp et al. 2008; Manso \& Castro-Gomes, 2015).

Thus, regarding the number of materials presented the objective of this work was to evaluate two materials for use in vertical gardens.

\section{Methodology}

The work was developed from September $14^{\text {th }}, 2019$ to February $2^{\text {nd }}, 2020$ in a residence located at coordinates $20^{\circ} 26^{\prime} 16.1^{\prime \prime S}, 51^{\circ} 20^{\prime} 58.4^{\prime \prime} \mathrm{W}$, in the municipality of Ilha Solteira, São Paulo state, Brazil, with panels fixed on a wall on the outside of the residence facing south, being a vertical masonry. 
The panels had dimension of $50 \times 80 \mathrm{~cm}$, with 24 pockets, which varied from $10-12 \mathrm{~cm}$ in width by $15-20 \mathrm{~cm}$ in height and volume between 450 and 600 grams (these variations in dimensions are problems related to those who made them). For panels assembly it was used green plastic canvas, “cacharel” fabric (gray fabric) and felt (green fabric) (Figures 1 and 2). The material for confection was purchased directly from a representative in the municipality of São José do Rio Preto and Ribeirão Preto, both in São Paulo state.

Figure 1. Aspect of the panels.

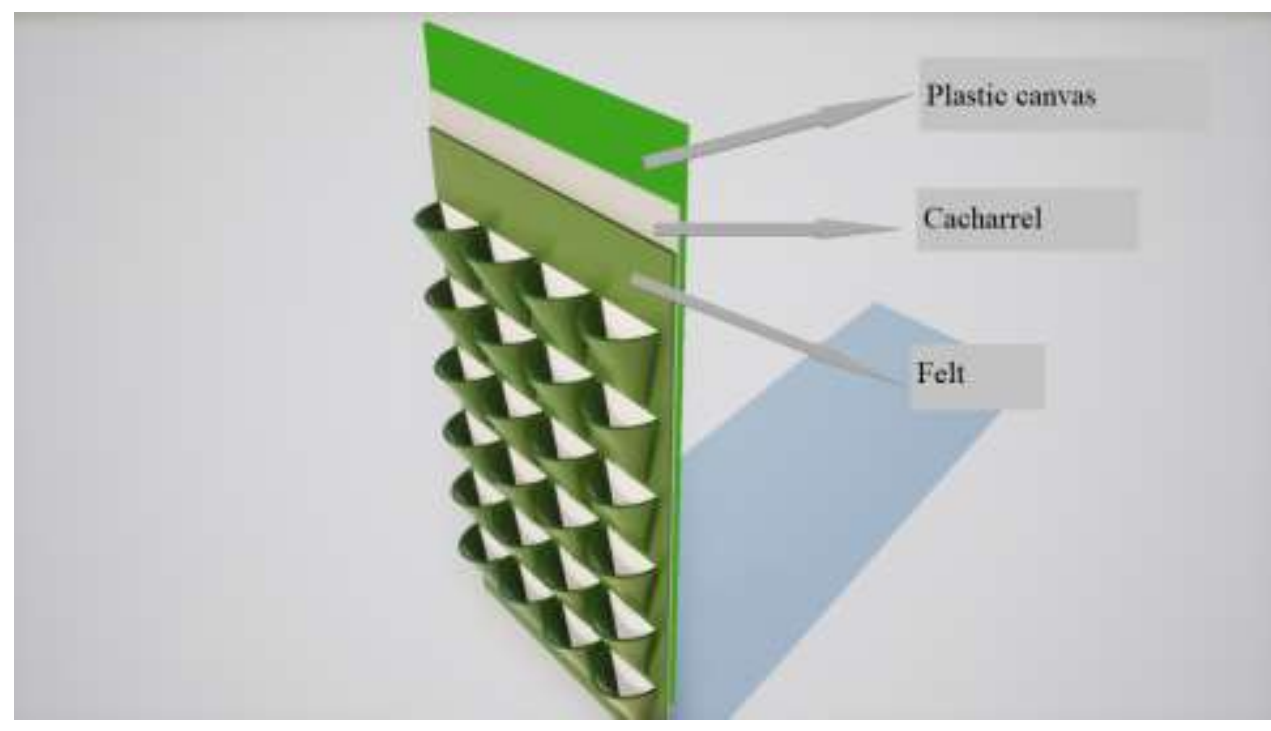

Source: Authors.

Figure 2. Panel made with cacharrel (grey fabric at back) and felt (green fabric at the front), and back with green plastic canvas.

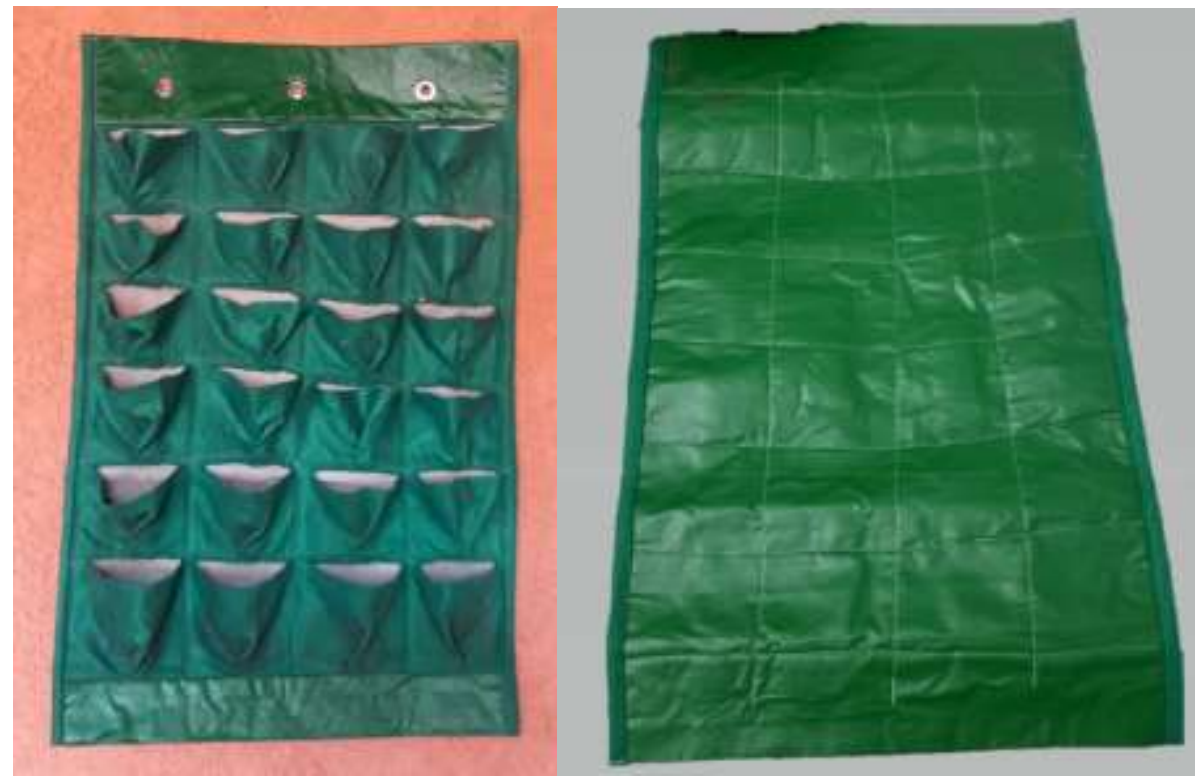

Source: Authors.

The panels were fixed on metal hooks $1.9 \mathrm{~m}$ from the ground and $15 \mathrm{~cm}$ apart. The species used was Tradescantia zebrina (Figure 3), a plant classified as typical foliage of equatorial climates, tropical and subtropical, widely used for 
decoration due to its compact aspect (small size) and its leaves of purple and green colours. This plant has good adaptation to full sun and half shade and has a perennial life cycle (Patro, 2013).

Figure 3. Aspect of plant species used (Tradescantia zebrina).

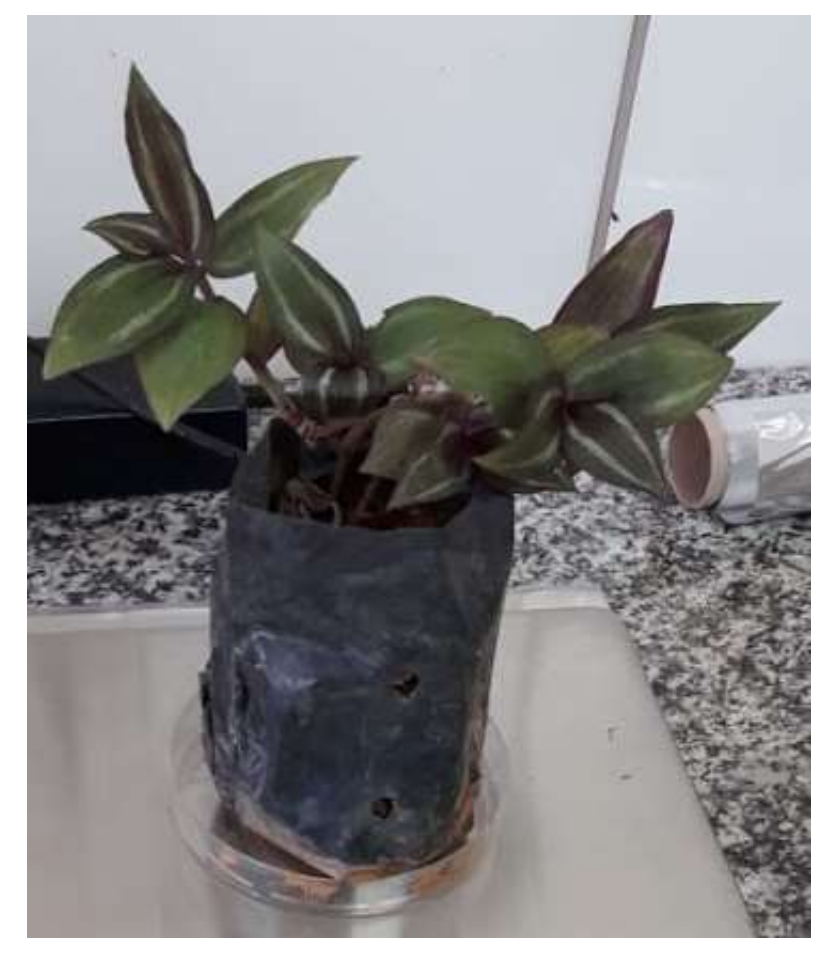

Source: Authors.

Containers of both materials were made, $8 \mathrm{~cm}$ high and $7 \mathrm{~cm}$ in diameter, which were filled with commercial substrate and measured the mass of three empty containers, filled with dry commercial substrate and subsequently wet (at the moment and 24 hours later).

In samples of $10 \mathrm{~cm} \times 10 \mathrm{~cm}$ from both fabrics (three replications of each one), dry and wet weight were measured, at the time and after 2, 4 and 8 hours. The dry and wet weight (at the time and 1 hour later) of the panel with the plant and its moist substrate was measured.

The temperature was measured daily, for 15 days, during the period from 01/19/2020 and 02/02/2020; the temperatures of the environment, the wall on which the panels were installed, the panels and the region behind the panels were measured with a digital infrared thermometer for surfaces. Plants were irrigated at $10 \mathrm{AM}$ and temperatures were measured once a day at $1 \mathrm{PM}$.

On 02/04/2020, the green and gray panel plants (two replications of each one) were removed and weighed (g), and also 1 plant with the appropriate panel filling; thus it was possible to estimate the filling of the panel and its visual aspect.

The cost was estimated based on the materials and labour used in making the panels, and expressed in $\mathrm{R} \$ / \mathrm{m}^{2}$.

\section{Results and Discussion}

Table 1 shows the results of the container weights (volume of $0.14 \mathrm{~g} \mathrm{~cm}^{-3}$ ) of test made with grey and green fabric; it is observed that there is no significant difference between the tissues when filled and wet. 
Table 1. Weight $(\mathrm{g})$ of test containers, containers + substrate, containers + wet substrate and containers + wet substrate after 2 hours

\begin{tabular}{ccccc}
\hline Fabric & Container $(\mathbf{g})$ & $\begin{array}{c}\text { Containers + } \\
\text { substrate }(\mathbf{g})\end{array}$ & $\begin{array}{c}\text { Containers + wet } \\
\text { substrate }(\mathbf{g})\end{array}$ & $\begin{array}{c}\text { Containers + wet } \\
\text { substrate after 2 hours } \\
(\mathbf{g})\end{array}$ \\
\hline Grey & $9.05 \mathrm{a}$ & $358.00 \mathrm{a}$ & $589.10 \mathrm{a}$ & $571.40 \mathrm{a}$ \\
Green & $8.08 \mathrm{~b}$ & $350.03 \mathrm{a}$ & $589.90 \mathrm{a}$ & $573.10 \mathrm{a}$ \\
\hline CV\% & 1.94 & 2.99 & 3.07 & 3.10 \\
F & $51.74^{* *}$ & $0.85^{\mathrm{ns}}$ & $0.01^{\mathrm{ns}}$ & $0.01^{\mathrm{ns}}$ \\
\hline
\end{tabular}

Means followed by the same letter in the column do not differ by the F test at $5 \%$ significance. Source: Authors.

Table 2 showed data on plant weight with the root ball $(\mathrm{g})$, as well as the mass of the panel (with green felt) dry, wet at the moment and after $1 \mathrm{~h}$.

Table 2. Weight (kg) plant with wet substrate, dry and wet panel (at the moment and $1 \mathrm{~h}$ later).

\begin{tabular}{ccccc}
\hline $\begin{array}{c}\text { Plant weight with wet } \\
\text { substrate (kg) }\end{array}$ & $\begin{array}{c}\text { Dry panel weight } \\
(\mathbf{k g})\end{array}$ & $\begin{array}{c}\text { Wet panel weight } \\
\mathbf{( k g )}\end{array}$ & $\begin{array}{c}\text { Panel weight after 1 } \\
\text { hour wet (kg) }\end{array}$ & Total weight* (kg) \\
\hline 0.271 & 0.470 & 1.332 & 2.048 & 7.836 \\
\hline
\end{tabular}

$*$ Weight of the plant with wet substrate $(24$ pockets $)+$ Wet panel weight $=$ Total weight. Source: Authors.

As shown in Table 1, there was no significant difference between fabrics, so it may be inferred that, regardless of their manufacture, there will be no difference between the types of panels, and that, according to Table 2 , its weight when wet and installed will be $7,836 \mathrm{~kg}$ (19.59 $\mathrm{kg} \mathrm{m}^{-2}$ ). According to Vertiflor ${ }^{\circledR}$ (2019) and Urban Therapy (2019), the weight of the panel, made with felt (recycled polyester), planted and wet, is approximately $25 \mathrm{~kg} \mathrm{~m}^{-2}$, being higher than that obtained in this study, taking into account considering the type of material used.

Figure 4 shows temperature measurement data, in ${ }^{\circ} \mathrm{C}$, performed from January $19^{\text {th }}, 2020$ to February $2^{\text {nd }}, 2020$. 
Figure 4. Data of monitoring temperature of the environment, the wall, the panels and the area behind the panels obtained over a period of 15 days.

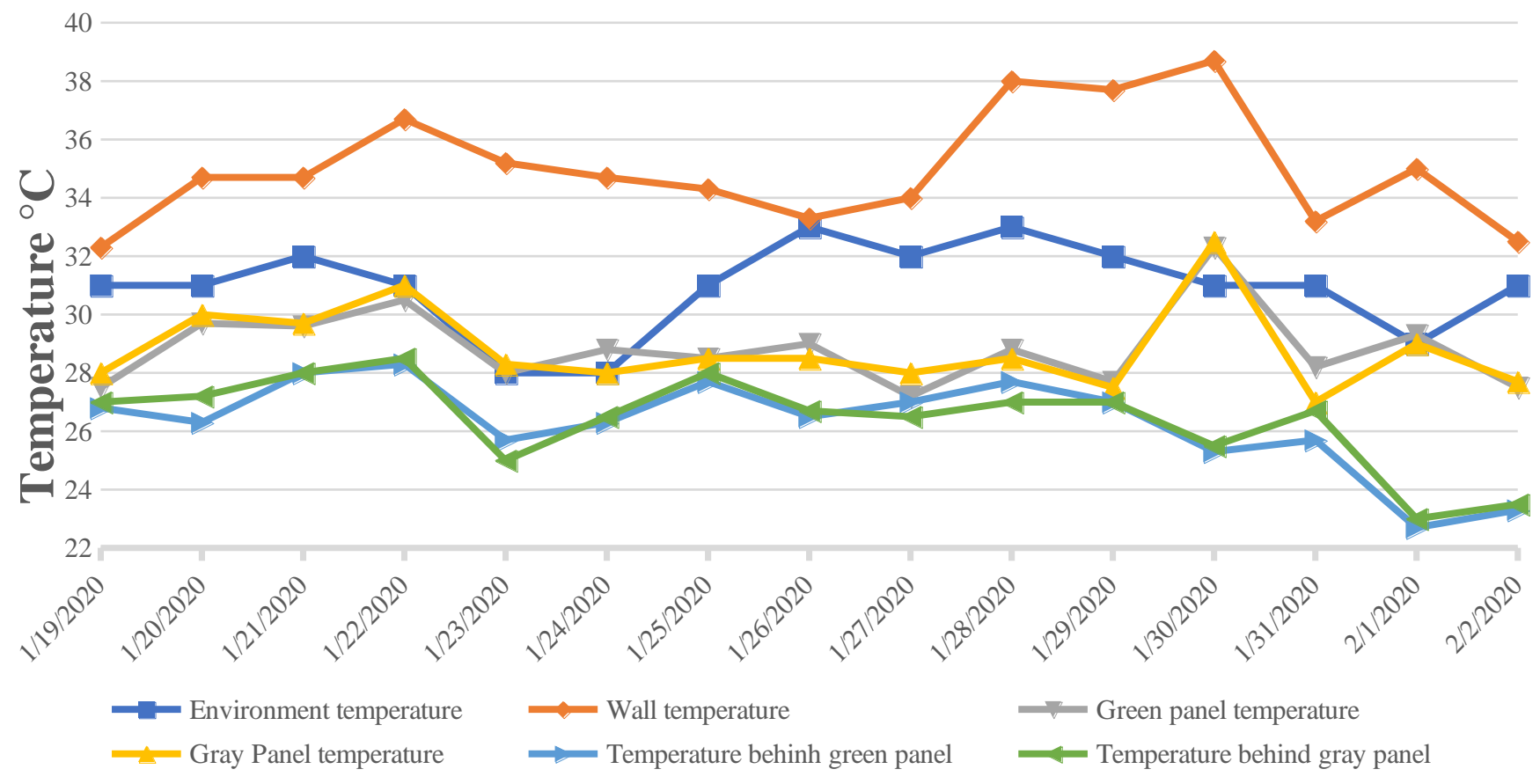

Source: Authors.

The average temperature of the environment and the wall was, respectively, $31.6^{\circ} \mathrm{C}$ and $35.0^{\circ} \mathrm{C}$, as observed in Figure 1 , with the average difference between these temperatures being $3.4^{\circ} \mathrm{C}$.

The wall temperature is always higher than the environment temperature; this is due to the fact that the wall is made of structural masonry, thus presenting two important properties related to heat storage: thermal conductivity and heat capacity. Thermal conductivity is related to the material's capacity to conduct heat to its interior, and heat capacity refers to the material's capacity to store heat in its volume. Masonry has high thermal conductivity, as well as high heat capacity, justifying the wall always presenting higher temperatures than the environment (Gartland, 2008).

Tables 3 and 4 present data on the thermal damping that occurs in the panels and in the region behind them, in relation to the wall, for the green and gray panels, respectively. 
Table 3. Thermal damping of the wall surface in relation to the green panel and the wall area behind it.

\begin{tabular}{|c|c|c|c|c|c|c|}
\hline $\begin{array}{c}\text { Sample } \\
\text { days }\end{array}$ & $\begin{array}{c}\text { Wall } \\
\text { temperature } \\
\left({ }^{\circ} \mathbf{C}\right)\end{array}$ & $\begin{array}{l}\text { Environment } \\
\text { temperature }\end{array}$ & $\begin{array}{c}\text { Panel } \\
\text { temperature } \\
\left({ }^{\circ} \mathbf{C}\right)\end{array}$ & $\begin{array}{l}\text { Thermal damping } \\
\text { of the panel }\left({ }^{\circ} \mathrm{C}\right)\end{array}$ & $\begin{array}{c}\text { Temperature } \\
\text { behind the } \\
\text { panel }\left({ }^{\circ} \mathrm{C}\right)\end{array}$ & $\begin{array}{c}\text { Thermal } \\
\text { dampening behind } \\
\text { the panel }\left({ }^{\circ} \mathrm{C}\right)\end{array}$ \\
\hline $01 / 19$ & 32.3 & 31.0 & 27.5 & 4.8 & 26.8 & 5.5 \\
\hline $01 / 20$ & 34.7 & 31.0 & 29.7 & 5.0 & 26.3 & 8.4 \\
\hline $01 / 21$ & 34.7 & 32.0 & 29.6 & 5.1 & 28.0 & 6.7 \\
\hline $01 / 22$ & 36.7 & 31.0 & 30.5 & 6.2 & 28.3 & 8.4 \\
\hline $01 / 23$ & 35.2 & 28.0 & 28.0 & 7.2 & 25.7 & 9.5 \\
\hline $01 / 24$ & 34.7 & 28.0 & 28.8 & 5.9 & 26.3 & 8.4 \\
\hline $01 / 25$ & 34.3 & 31.0 & 28.5 & 5.8 & 27.7 & 6.6 \\
\hline $01 / 26$ & 33.3 & 33.0 & 29.0 & 4.3 & 26.5 & 6.8 \\
\hline $01 / 27$ & 34.0 & 32.0 & 27.2 & 6.8 & 27.0 & 7.0 \\
\hline $01 / 28$ & 38.0 & 33.0 & 28.8 & 9.2 & 27.7 & 10.3 \\
\hline $01 / 29$ & 37.7 & 32.0 & 27.7 & 10.0 & 27.0 & 10.7 \\
\hline $01 / 30$ & 38.7 & 31.0 & 32.3 & 6.4 & 25.3 & 13.4 \\
\hline $01 / 31$ & 33.2 & 31.0 & 28.2 & 5.0 & 25.7 & 7.5 \\
\hline $02 / 01$ & 35.0 & 29.0 & 29.3 & 5.7 & 22.7 & 12.3 \\
\hline $02 / 02$ & 32.5 & 31.0 & 27.5 & 5.0 & 23.3 & 9.2 \\
\hline \multicolumn{4}{|c|}{ Average thermal damping $\left({ }^{\circ} \mathrm{C}\right)$} & 6.16 & & 8.71 \\
\hline
\end{tabular}

Source: Authors.

Table 4. Thermal damping of the wall surface in relation to the gray panel area of the wall behind it.

\begin{tabular}{|c|c|c|c|c|c|c|}
\hline $\begin{array}{l}\text { Sample } \\
\text { days }\end{array}$ & $\begin{array}{c}\text { Wall } \\
\text { temperature } \\
\left({ }^{\circ} \mathrm{C}\right)\end{array}$ & $\begin{array}{l}\text { Environment } \\
\text { temperature }\end{array}$ & $\begin{array}{c}\text { Panel } \\
\text { temperature } \\
\left({ }^{\circ} \mathrm{C}\right)\end{array}$ & $\begin{array}{c}\text { Thermal damping of } \\
\text { the panel }\left({ }^{\circ} \mathrm{C}\right)\end{array}$ & $\begin{array}{l}\text { Temperature } \\
\text { behind the } \\
\text { panel }\left({ }^{\circ} \mathrm{C}\right)\end{array}$ & $\begin{array}{c}\text { Thermal } \\
\text { dampening } \\
\text { behind the panel } \\
\left({ }^{\circ} \mathrm{C}\right)\end{array}$ \\
\hline $01 / 19$ & 32.3 & 31.0 & 28.0 & 4.3 & 27.0 & 5.3 \\
\hline $01 / 20$ & 34.7 & 31.0 & 30.0 & 4.7 & 27.2 & 7.5 \\
\hline $01 / 21$ & 34.7 & 32.0 & 29.7 & 5.0 & 28.0 & 6.7 \\
\hline $01 / 22$ & 36.7 & 31.0 & 31.0 & 5.7 & 28.5 & 8.2 \\
\hline $01 / 23$ & 35.2 & 28.0 & 28.3 & 6.9 & 25.0 & 10.2 \\
\hline $01 / 24$ & 34.7 & 28.0 & 28.0 & 6.7 & 26.5 & 8.2 \\
\hline $01 / 25$ & 34.3 & 31.0 & 28.5 & 5.8 & 28.0 & 6.3 \\
\hline $01 / 26$ & 33.3 & 33.0 & 28.5 & 4.8 & 26.7 & 6.6 \\
\hline $01 / 27$ & 34.0 & 32.0 & 28.0 & 6.0 & 26.5 & 7.5 \\
\hline $01 / 28$ & 38.0 & 33.0 & 28.5 & 9.5 & 27.0 & 11.0 \\
\hline $01 / 29$ & 37.7 & 32.0 & 27.5 & 10.2 & 27.0 & 10.7 \\
\hline $01 / 30$ & 38.7 & 31.0 & 32.5 & 6.2 & 25.5 & 13.2 \\
\hline $01 / 31$ & 33.2 & 31.0 & 27.0 & 6.3 & 26.7 & 6.5 \\
\hline $02 / 01$ & 35.0 & 29.0 & 29.0 & 6.0 & 23.0 & 12.0 \\
\hline \multirow[t]{2}{*}{$02 / 02$} & 32.5 & 31.0 & 27.7 & 4.8 & 23.5 & 9.0 \\
\hline & \multicolumn{3}{|c|}{ Average thermal damping $\left({ }^{\circ} \mathrm{C}\right)$} & 6.19 & & 8.59 \\
\hline
\end{tabular}

Source: Authors.

It may be observed that there was an average thermal damping of 6.16 and $6.19{ }^{\circ} \mathrm{C}$ between the wall temperatures in relation to the green and gray panels, and the areas behind these 8.71 and $8.59{ }^{\circ} \mathrm{C}$, respectively. This is explained by Labaki et al. (2011), who says that vegetation acts differently from other ways, as its function is to block solar incidence. The energy balance of vegetation cover is composed of thermal exchanges by radiation and convection, evapotranspiration of soil and plants, in addition to thermal conduction and heat storage in the soil layers (Gagliano et al., 2015), which explains the results shown in Tables 3 and 4.

For Chen et al. (2013), the vertical garden is an instrument capable of removing heat from the wall and the air cushion formed by the space between the panel and the wall, so the smaller the cavity, the greater the thermal efficiency, as the ventilation and the exchange of heat by convection, as seen in the present work. 
According to Silva et al. (2011), vegetation acts through passive cooling based on two mechanisms: the shading cast by plants, which decreases the conversion of radiant energy into sensible heat and which through this decreases the surface temperatures of objects that by they have been shaded; and the evapotranspiration of leaves surface and the substrate that results in this system cooling of this assembly and of the air passing through its surface, due to the exchange of latent heat. This explains the fact that the panels with vegetation have an average temperature lower than the wall that has no vegetation at all.

Wong et al. (2009) performed research in order to analyse the thermal efficiency of different types of green walls founding reduction in wall surface temperature up to $11.58{ }^{\circ} \mathrm{C}$; Matheus et al. (2016) studied the influence of vertical gardens in a building in spring-summer period and observed a $15-30^{\circ} \mathrm{C}$ reduction in external surface temperature of wall; on the other hand, Lima Júnior (2018) analysed the influence of vertical gardens on opaque walls and observed that there was difference of $5.9{ }^{\circ} \mathrm{C}$ between the average temperatures of the external surfaces with and without the vertical gardens prototypes; thus, comparing the results obtained by the aforementioned authors with those of this work, it may be noticed that the temperature reduction presented coherent values and the variations may have occurred due to the local climate in each experiment, the material used to make the panels, as well as the plant species used.

The two materials used to make the panels (green felt and cacharrel) had similar performance, as may be seen in Tables 1, 3 and 4 and Figure 4.

As for the visual aspect, a plant with the proper filling of the panel weighed $38.9 \mathrm{~g}$ (Figure 5).

Figure 5. Aspect of Tradescantia zebrina, with adequate filling of the panel.

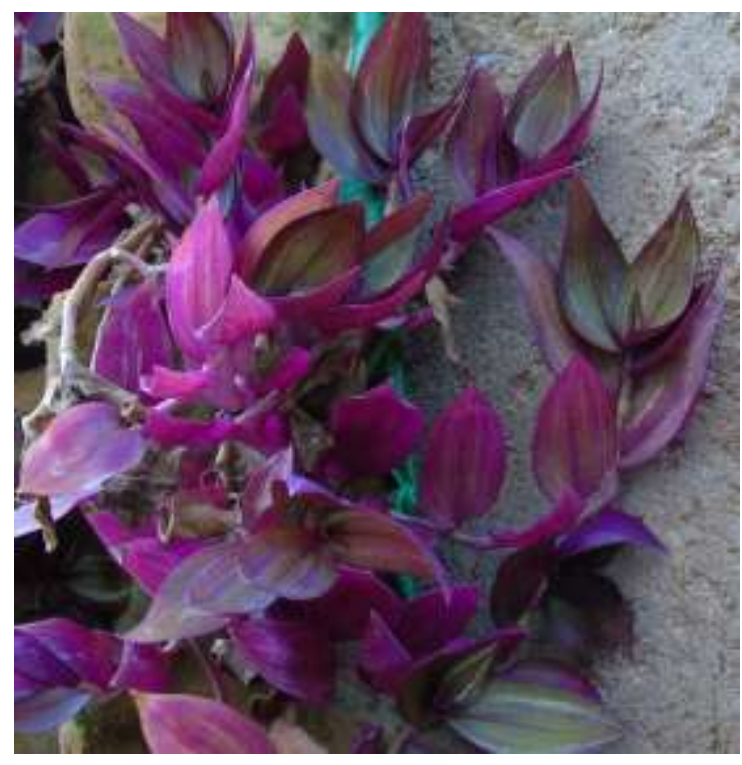

Source: Authors.

The evaluation of total weight of plants in each panel is shown in Table 5, and the expected value would be $933.6 \mathrm{~g}$, considering the weight of the one with ideal filling (38.9 $\mathrm{g}$ x 24 pockets). This non-development of plants, as well as the lack of complete filling of the panels, was due to a failure in the confection, as the pockets ranged from 10-12 cm in width by $15-20$ $\mathrm{cm}$ in height and volume between 450 and $600 \mathrm{~g}$. 
Table 5. Total weight of plants (g) in each panel.

\begin{tabular}{cc}
\hline PANEL & Total weight of plants (g) \\
\hline GREEN & 516.35 \\
GRAY & 509.10 \\
\hline
\end{tabular}

Source: Authors.

Table 6 shows the value of $0.4 \mathrm{~m}^{2}$ (from the panel) and $\mathrm{m}^{2}$ for comparison.

Table 6. Comparison of values in Brazilian currency of components and products used in making the panel made with green and gray fabric.

\begin{tabular}{ccccc}
\hline $\begin{array}{c}\text { Material (Fabrics, Canvas, eyelets) }+ \\
\text { labour }\end{array}$ & Value of $\mathbf{0 . 4} \mathbf{~ m}^{\mathbf{2}}$ (each panel) $-\mathbf{R} \mathbf{\$}$ & \multicolumn{2}{c}{ Value of $\mathbf{~ m}^{\mathbf{2}}-\mathbf{R} \mathbf{\$}$} \\
\hline Panel & Green/Gray & Gray & Green/Gray & Gray \\
Without plants & 83.52 & 85.79 & 207.60 & 214.47 \\
With 24 units of Tradescantia zebrina & 115.44 & 117.71 & 239.52 & 246.39 \\
\end{tabular}

Source: Authors.

The total cost of the panel made with green and gray fabrics was $\mathrm{R} \$ 207.60 / \mathrm{m}^{2}$ while the cost of the panel made with gray fabric was $\mathrm{R} \$ 214.47 / \mathrm{m}^{2}$, both without considering the value of the plants. If the plant in question (Tradescantia zebrina) were added, the amount of $\mathrm{R} \$ 31.92$ would be added to each panel, relating to 24 units (Table 6).

On the market it is possible to find several panels similar to the one developed in this work with prices ranging from $\mathrm{R} \$ 280.00\left(1 \times 1 \mathrm{~m}-1 \mathrm{~m}^{2} ; 72\right.$ pockets) to $\mathrm{R} \$ 360.00\left(0.7 \times 2.3 \mathrm{~m}-1.61 \mathrm{~m}^{2} ; 56\right.$ pockets / $\left.\mathrm{R} \$ 223.60 / \mathrm{m}^{2}\right)$; these values were found on the Mercado Livre and Loja Flash websites, sold by several sellers. According to Kehdi (2019), the final price of a vertical garden may vary greatly depending on the type of structure, vegetation and irrigation system, ranging from $R \$ 800.00$ to $R \$$ $1,700.00 / \mathrm{m}^{2}$.

Thus, it may be reported that the value of the panels in this work is consistent with the price of those sold in the market, even presenting lower values in relation to those of the researched products; it may also be concluded that the prices of both panels made were very similar, as well as all the other aspects analysed in this work.

\section{Conclusion}

Both materials used in the manufacture of vertical garden panels proved to be viable for this purpose. In addition, the panels developed obtained satisfactory results in relation to thermal damping.

\section{References}

Blanc, P. (2008). The Vertical Garden: A scientific and artistic approach. http://www.verticalgardenpatrickblanc.com/documents.

Chen, Q., Li, B. \& Liu, X. (2013). An experimental evaluation of the living wall system in hot and humid climate. Energy and Buildings, 61, 298-307. https://doi.org/10.1016/J.ENBUILD.2013.02.030.

Costa, C. S. Jardins Verticais - uma oportunidade para as nossas cidades? http://www.vitruvius.com.br/revistas/read/arquitextos/12.133/3941.

Ekren, E. (2017). Advantages and risks of vertical gardens. Journal of Bartin Faculty of Forestry, 19(1), 51-57. https://doi.org/10.24011/barofd.293124. 
Research, Society and Development, v. 10, n. 7, e41510716709, 2021

(CC BY 4.0) | ISSN 2525-3409 | DOI: http://dx.doi.org/10.33448/rsd-v10i7.16709

Gagliano, A., Detommaso, M., Nocera, F. \& Evola, G. (2015). A multi-criteria methodology for comparing the energy and environmental behavior of cool, green and traditional roofs. Building and Environment, 90, 71-81. https://doi.org/10.1016/j.buildenv.2015.02.043.

Gartland, L. (2008). Ilhas de calor: como mitigar zonas de calor em áreas urbanas. Oficina de Textos.

Kehdi, G. (2019). Jardins Verticais. https://www.gabrielkehdi.com/single-post/2019/04/11/Jardins-Verticais.

Labaki, L. C., Santos, R. F., Bueno-Bartholomei, C. L. \& Abreu, L. V. (2011). Vegetação e conforto térmico em espaços urbanos abertos. Revista Fórum Patrimônio - Ambiente Construído e Patrimônio Sustentável, 4(1), 1-18.

Lima Júnior, J. E. (2018). Avaliação da influência de um sistema de fachada viva: o estudo de caso da planta Sphagneticola trilobata em condições de inverno de Curitiba. Maldivas: Novas Edições Acadêmicas.

López, S. \& Narváez, P. (2015). Fachadas Vegetales: moda o alternativa sostenible. https://s3.amazonaws.com/academ ia.edu.documents/48963752/articulo_fachadas_vegetales.pdf?response-content-disposition=inline\%3B\%20filename\%3DFachadas_vegetales.pdf\&X-AmzAlgorithm=AWS4-HMAC-SHA256\&X-Amz-Credential=AKIAIWOWYYGZ2Y53UL3A\%2F20200229\%2Fus-east-1\%2Fs3\%2Faws4_request\&X-AmzDate $=20200229 \mathrm{~T} 151805 Z \& X-A m z-E x p i r e s=3600 \& X-A m z-S i g n e d H e a d e r s=h o s t \& X-A m z-$ Signature=131590ca583423cb211e65ffc40c1010653abde2da3f65aecf4507c953a21a35.

Manso, M \& Castro-Gomes, J. (2015). Green wall systems: A review of their characteristics. Renewable and Sustainable Energy Reviews, 41, 863-871. https://doi.org/10.1016/j.rser.2014.07.203.

Matheus, C., Caetano, F. D. N., Morelli, D. D. O. \& Labaki, L. C. (2016). Desempenho térmico de envoltórias vegetada sem edificações no sudeste brasileiro. Ambiente Construído, 16(1), 71-81. http://dx.doi.org/10.1590/s1678-86212016000100061.

Patro, R. (2013). Lambari - Trandescantia zebrina. https://www.jardineiro.net/plantas/lambari-tradescantia-zebrina.html.

Petty, N. A. (2003). Vertical is the new horizon: an overview of vertical gardening in the 21st century. https://getd.libs.uga.edu/pdfs/petty_nicholas_a_200812_mla.pdf.

Saldiva, P. (2017). Áreas verdes garantem saúde e qualidade de vida à população. https://jornal.usp.br/atualidades/areas-verdes-garantem-saude-e-qualidadede-vida-a-populacao/.

Sharp, R., Sable, J., Bertram, F., Mohan, E. \& Peck, S. (2008). Introduction to Green Walls: technology, benefits \& design. In: Green Roofs for Healty Cities. http://www.greenroofs.net/components/com_lms/flash/Green\%20Walls\%20Intro\%20908b.pdf.

Silva, I. M., Gonzales, L. R. \& Silva Filho, D. F. (2011). Recursos naturais de conforto térmico: um enfoque urbano. Revista Brasileira de Arborização Urbana, 6(4), 35-50.

Urban Terapy. (2019). Fytotextile. https://www.terapiaurbana.es/wp-content/uploads/2018/02/Sistema-Fytotextile-2018-v2.pdf.

Vertiflor. (2019). Sistemas de jardinería vertical. https://www.vertiflor.com/blog/decidete-por-un-jardin-vertical-vertiflor.

Wong, N. H., Tan, A. Y. K., Tan, P. Y. \& Wong, N. C. (2009). Energy simulation of vertical greenery systems. Energy and Buildings, 41, 1401-1408. https://doi.org/doi:10.1016/j.enbuild.2009.08.010. 